\title{
An Investigation of Verb-Forms Errors in the Spoken English of English-Majors and Non-English Majors at Emirates Canadian University College/ U.A.E.
}

\author{
Dr. Mohammed Hamid Al-Ta'ani \\ Assistant Professor \\ Department of English Language and Translation \\ Emirates Canadian University College (ECUC) \\ Umm Al-Quwain, United Arab Emirates. \\ Tel: +971-557-483-918Ｅ-mail: dr.mattar1989@ hotmail.com
}

Received: January 20, 2019 Accepted: February 12, 2019 Published: February 13, 2019

doi:10.5296/jsel.v7i1.14342 URL: https://doi.org/10.5296/jsel.v7i1.14342

\begin{abstract}
This study aimed at identifying the strategies used by University students in learning English as a second language and their weaknesses in the grammatical and the lexical use of the English verb-forms. A total number of (8) university students were interviewed personally. Interviews were taped and each student's speech was transcribed in order to be analyzed. The grammatical and the lexical errors were categorized and put to further analysis and investigation which explained the reasons and strategies behind their occurrences. The findings indicated that: - the learners' errors were developmental and they benefited from instructions, most of the frequent errors were due to interference of the first language and the majority of errors were interlanguages errors, simplification and overgeneralization proved to be the most two widely used strategies in learning a second language and the learners' motivation to communicate may exceed their motivation to produce grammatically correct sentences. A major conclusion of this study is the need of the English-major students for a remedial course in which they may have the opportunity to practice the basic structures of the English Language. Finally, based on the results of this study some pedagogical implications for English teachers and university instructors, curriculum designers and policy makers were highlighted.
\end{abstract}

Keywords: verb-forms errors, sources of errors, lexical errors, strategy, grammatical errors 


\section{Introduction \& Background}

The significance of the errors made by students learning a second language (L2) seems to receive great attention in psycholinguistic studies. Within this psycholinguistic framework, these errors are no more signs of inhibition but indicators to the learner's language competence at a certain point of time and are as important as those errors produced by the first language (L1) learners.

Corder says that the errors produced by a child learning his mother tongue are not regarded as errors in any sense "but rather as a normal childlike communication which provides evidence of the state of his linguistic development at the moment "(Corder, 1974). And just as children's language follows a developmental sequence, it has been suggested that "the differences between the way a second language is often spoken and the way the language is spoken by native speakers are systematic" (Richards, 1974).

Corder suggests that such errors should be systematically analyzed so that an insight could be gained into the learner's "built-in-syllabus".

It is obvious that this descriptive approach to learners' errors formulates an alternative hypothesis to the hypothesis made by the contrastive analysis prescriptive approach. To the contrastive linguists, the main source of errors in L2 production is the interference from the first language. But the errors analysis theory first draws a distinction between two kinds of errors: performance errors, which are due to non-linguistic factors e.g. memory, fatigue, psychological state, etc., and errors that give evidence of the speaker's competence in the foreign language.

Richards, 1971, pp.173-181 (as cited in Bootchy,2008) classified errors into one of the three main categories according to its anticipated cause. They are: interlanguage errors, intralingual errors and developmental errors. Interlanguage errors are "errors which are caused by the interference of the learner's mother tongue." While intralingual errors are" errors which reflect the general characteristics of rule learning." This type of error can further be subdivided into

1- Overgeneralization: extension of the target language (TL) rules to areas where they do not apply.

2- Ignorance of rule restrictions.

3- Incomplete application of rules: errors resulting from the attempt to communicate in the TL without having acquired the necessary grammatical forms to do so.

While developmental errors refer to "errors which appear because the learners try to build up hypotheses about English Language from his or her limited experiences of it in the classroom or textbook. Developmental errors often occur at the first stages of language learning and positively viewed as a channel towards improvement. (Phettongkam,2013). (Dulay ,1982) mentioned that error classification yield benefits to teachers by allowing them to record data, observe progress and plan remedial lessons.

From the above classification of errors, one can notice that errors analysis theorists try to 
describe the speech of the adult L2 learners in its own terms as well as in its relativeness to native speech.

"Speech errors are no longer regarded as emanating from the subconscious, but rather as concrete misapplications at the level of lexical selection, word formation and structural organization." (Steinberg, 1999, pp. 121).Speech errors can provide us with principles by which we can cope with inefficiency of the English teaching and learning, specially speaking skill. Findings on frequency, level, gravity, sources and types of spoken errors in all levels can be of paramount contribution to all stakeholders involved in ELT in general and language teachers in particular.( Rezai \& Heshmatian, 2013).

Shridar (1980) (as cited in Amin, B.2014) states that by identifying the learner's errors educators are able to: (a) determine the sequences of presentation of target items in textbook (b). Emphasis, explain and practice a various items about language target (c) plan and arrange remedial lesson and exercise.

Recent research on L2 learning has pointed out that these kinds of errors are similar to the errors produced by children acquiring their mother tongue and that; in general, similar processes are involved in L1 acquisition and L2 learning (Ravem, 1978; Ervin-Tripp, 1978; Bailey, Madden and karshen, 1978).

Although Enquist (1979), who found that the acquisition of morphemes in English as a second language was different from their acquisition in English as a first language, did not agree with these researchers on the similarities in the two processes, she agreed with others on the fact that a sequence seems to exist in the acquisition of some structures which is common to all L2 learners. That is, the relative difficultly of the language items is a very crucial factor in determining the order of their acquisition (Enquist, 1980; Tahririan, 1978; Bailey, Madden \& Krashen, 1978).

These findings are all evidence to the fact that L1 has a very little effect on L2 learning and that most of the errors committed by L2 learners are due to some intra language factors.

It can be concluded, here, that L2 learning, similar to L1 acquisition, is both systematic and creative. Thus, the L2 learner, being exposed to the L2 data formulates rules or hypotheses about the language, and then tests them according to a certain feedback. If this is so, then we can gain a better understanding of what is going on in the learner's mind by the systemically analyzing the errors that occur in his/her language production, which is the general aim of this study.

\section{Statement of the Problem}

The researcher's own experience with adult learners of English as a foreign language seems to reveal a disquieting lack of improvement or a very slow, if any, acquisition of the English grammatical morphemes. Although the learners receive a great deal of instruction and correction in the use of the grammatical markers, they only seem to increase their knowledge of the contexts in which to use the markers without being able to monitor their language 
production.

So the main purpose of this study is to gain a better understanding and a more precise estimate of the varying degrees of foreign language competence they have, and to assess the degree to which they benefit from language instruction, in general, and from instruction in the use of the grammatical markers in particulars.

And this will be done by analyzing the errors in the speech of Emirates Canadian University College (ECUC) students from both first and second years and from both English major and non-English major students.

\section{Purposes of the Study}

The specific purposes of this study are:

1- Identifying the errors produced by the subjects in both the lexical and the grammatical use of the English verb, describing these errors, and explaining the reasons behind their occurrence.

2- Telling the differences between these four groups in the degree of accuracy of the verb use.

\section{Significance of the Study}

Such a study is of great help in providing the English-teacher researcher in identifying the extent to which his students benefit from the existing language program and methods of teaching.

It also helps in identifying his students' strengths and weaknesses in dealing with verbs in English so that certain procedures may be followed in tracing such weaknesses and overcoming them.

\section{Hypotheses}

This study has two main hypotheses:

1- First and second- year -English -major students will show a high degree of agreement with respect to the degree of accuracy of the lexical and grammatical use of the English verb.

2- First and second-year non-English -major students will show a high degree of agreement with each other with respect to the degree of accuracy of the lexical and grammatical use of the English verb.

As clear, there is no intention to compare the English - major students with the non-English major students. So, while the dependent variable is the number of errors, the independent variable is the grade level only. 


\section{Definition of Terms}

An error: - A deviation from what is normally produced by adult native speakers of the language.

A strategy: - is "The application of a regular and identifiable learning approach to the new language, whether conscious or not." (Chamot,1978)

Speaking: - is the form of oral correspondence between the speaker and the hearer in transforming ideas for reaching the goal of communication (Taufiqulloh, 2009 ).

\section{Limitations of the Study}

Although the researcher assumes that students who join universities have been exposed to the same levels of English, and that those who specialize in English have a considerable level of English Language proficiency as a pre-requisite for this specialization, he has the following limitations for his study:

The results of this study are not generalizable and limited to the four groups of subjects who participated in it.

The sample of this study is not a representative one since the subjects were not randomly chosen, and that was because most students, due to the lack of confidence in their English, refused to be interviewed and recorded.

It is also worth mentioning, here, that this small number of subjects, especially the non-English major students cannot represent a population of about five hundred students enrolled in the university program.

Although all those who volunteered for being interviewed and recorded were from the average students, the results of this study may be affected by factors which are due to the changes in the curriculum. In addition to the regular courses, first- year English- major students are enrolled in remedial courses in which they are exposed to different kinds of language instructions: grammar, reading, writing, speaking, pronunciation and listening.

\section{Literature Review}

Many studies have been done to examine learners' grammatical errors in written English (Willcott,1972; Farhat,1994;Mohaghegh and et al, 2011; Nassaji,2011; Sukasame, N \& et al, 2014 Abu shihab,2014 ;Owu-Ewie \& Lomotey, 2016; Mushin, M.,A,2016). Howbeit, few studies closely related to the present study undertaken have been reviewed as under.

Mariko (2007) (as cited in Rezai, M. \& Masood Heshmatian) conducted a study on grammatical development in SLA to identify Japanese learners' errors of spoken and written English in terms of noun, verb, and other part-of-speech -related errors. A substantial body of spoken and written data were used to investigate differences between spontaneous spoken 
production and less time- pressured written production to show the acquisition sequence of certain grammatical features in the different production modes. The results indicated that the lower level learners mostly made verbal errors while the learners at the advanced level made nominal errors more than other parts of speech. Furthermore, noun-related errors in written production did not seem to vanish over the course of development and some errors shared common development patterns, while others varied uniquely across proficiency levels.

An investigation made by Ting, S.H and et.at (2010) to analyze the grammatical errors of spoken English of (42) Malaysian University students who were less proficient in an oral communication course. The results showed that the six common errors made by the learners were prepositions, questions, articles, plural form of nouns, subject verb agreement and tense. Preposition and question were the most difficult for the less proficient students at a percentage of $35 \%$ of total errors, followed by word forms and articles. Some less frequent errors included subject- verb agreement, tenses, pronouns plural forms and misordering of sentential constituents. Also, the results showed an increase in grammatical accuracy in the learners' spoken English towards the end of the course.

Another study by (Kovac,2011) investigated the frequency and distribution of speech errors, as well as the influence of the task type on their rate. The participants were (101) engineering students in Croatia. A recorded speech sample in the English Language for nearly ten hours was transcribed, whereby more than three and a half thousands speech errors were recorded. Morphological errors were the most common due to significantly frequent omission errors such as articles. Statistical analysis of the influence of the task type of speech errors displayed that the retelling of a chronological order of events resulted in significantly higher rate of syntactic errors compared to other tasks.

Yoon, H.K.(2012) also carried out a study to investigate and identify the types of grammar errors that (84) Korean EFL learners made when they took the TOEIC Speaking Test part five and compared the results with the previous studies. The data were classified into the taxonomy of four surface strategies: omission, addition, misformation and misordering. He found that omission errors were the highest calculated $(74.9 \%)$, followed by misformation $(19.9 \%)$, addition $(3.5 \%)$ and misordering $(1.7 \%)$. He also found the error frequencies were very different from those observed in writing or interview tasks in the previous studies. Misformation errors were the highest followed by omission errors. He attributed this difference to the short test taking time and the task itself. The learners were unlikely to correct within the limited time since very few self-corrections were of served in their spoken answers. The study suggested that explicit grammar instructions and corrections were needed to teach speaking.

Tarawneh, R.T.and Islam, M.A. (2013) carried out an analysis of ungrammatical sentences in spoken English produced by some senior Jordanian English students. The findings indicated that subject-verb agreement and plural morpheme were the most common grammatical errors produced by the subjects. They attributed these errors to the following causes: carelessness, L1 interference, overgeneralization, and lack of competence. Based on the findings some recommendations were suggested. 


\section{$\triangle$ Macrothink}

Rezai \& Heshmatian (2013) investigated the morphological speaking errors of Iranian EFL learners across proficiency levels and gender. To this end, a corpus of 1399 tokens of speech morphology errors was collected. The learners' oral production was observed and recorded naturally using various communicative tasks in class. The errors were then detected, transcribed, coded and classified following James (1998) taxonomy of errors. The results indicated that mis-selection was the most frequent type at morphology level. Further, the results showed significant difference between genders regarding grammatical errors. Based on the findings of this study some suggestions and guidelines for English teachers, supervisors, and syllabus designers were highlighted to help EFL learners develop their intrelanguage knowledge of grammar through revisiting teaching methods and implementing remedial materials.

Saad, M.A and Murad, H.S. (2014) conducted a study to examine errors in the speech of less proficient speakers of English during their role-play presentations. Their samples were obtained during their enrolment in foundation English class where those who scored low during English Placement Test registered. The errors in their speech were analyzed by following surface structure taxonomy that specifies four types of errors, namely misformation, misordering, addition and omission. The findings indicated that omission accounted for the majority of errors identified, then misformation, addition and misordering respectively. In addition, linguistic description of errors identified verb form and word form to be the most frequent types of errors committed by the speakers.

Abd-Karim, N.and Mohamed, I.A.S. (2014) analyzed the errors made in grammar in the speech transcripts of (15) EOP learners. He classified the errors into (9)sub-categories: wrong use of nouns, wrong use of countable and uncountable nouns, nouns used as verbs, wrong use of prepositions in phrases, wrong addition of prepositions, wrong use of verbs, wrong use of phrasal verbs, wrong use of adjectives ending in -ed and -ing and redundant expressions. The results indicated that $t$ prepositions were the most frequent type of grammatical errors made by the learners and intra-lingual transfer was the most prominent source of errors. He suggested that ESL teachers must teach and focus on grammar and its use in contexts relevant to the learners' needs.

Another study was conducted by Al-Ahmadi, N.S. (2014) on (30) Saudi Arabian Students. Her purposes were to find out the most common speech errors that Saudi Students committed during the second language learning process and to provide further knowledge regarding the source of these errors. Oral interviews were used to collect the data, as the analysis in this study is based on spoken English. She interviewed the students personally. Interviews were transcripted in order to be analyzed. She found that misused singular and plural nouns were the most frequent errors at $27.67 \%$ followed by verb tenses $26.60 \%$, articles $25: 00 \%$.

Şena, Y and Mesu, K. (2017) also studied the students' use of plural in speaking in an EFL context. (48) Students' speaking exams were recorded during the oral exams in academic year 2014-2015.The recordings were transcribed by the researchers and the students' use of plural was analyzed. The results revealed that while students can use the plural appropriately with high-frequency words, they were found to use the singular form of an item in contexts where 
the plural form would be more appropriate. Considering the issue from a progressive perspective, it was found that this tendency did not persist in the long-run. While students from the ELT department were found to use plural appropriately, early level students were found to use plural "s" inappropriately. It was concluded that students' L1 (Turkish) and overgeneralization of rules in L2 might interfere with their use of plural in the early level, but the effect of L1 diminishes in the upper levels.

Ruminar, H. (2018) made a study on the grammatical errors across proficiency levels. The samples were collected from the second semester of Agriculture students' oral presentation in ESP class. They were grouped into high and low proficient students by using TOEFL test. The errors in their speech were classified by using surface structure taxonomy, namely: misformation, misordering, addition, omission, blends, and miscellaneous. The results revealed that misformation is the dominant error produced by both levels of proficiency, followed by omission, addition, miscellaneous, misordering, and blends.

\section{Methodology}

\subsection{Sample}

Eight students are chosen to be the sample of this study, (4) females and (4) males whose ages ranged between 19 to 20 years old in the spring semester of the academic year 2017-2018 as follows:

(Two) second- year English-major students.

(Two) first - year English -major students.

(Two) second - year - non -English -majors.

(Two) first- year- non- English- majors.

\subsection{Procedures}

The procedures consist of two main points:

\subsubsection{Data Collection}

This includes the following steps:-

a- Each participant was taped by being interviewed alone and asked some wh-questions that would elicit structures. Each interview lasted between (10-15) minutes. The questions focused on the students' personal affairs, the university affairs and some general facts of religion and humanity.

b- Each student's speech was emptied on a worksheet at the top of which appeared his/her name and field of specialization.

There were three recordings: one by the second-year English- major students, another by the first-year English-major students and the third by both the second and the first year non-English -major students. 


\subsubsection{Data Analysis}

\subsubsection{For Grammatical Use}

1) - Worksheets were read, the correct verbs were underlined and the wrong ones were circled.

2) - The wrong verbs were entered on specially prepared cards. And each card, including one type of errors, was given a heading written at its top.

3) - The errors under each category were counted and compared to the number of correct verbs of that type.

4) - Some of these error categories were not taken into consideration since they were committed by one group only and not frequent (i.e occurred once or twice), which may be due to the individual idiosyncratic strategies of the learner.

5) - The following categories were the most common errors and were taken into consideration for further analysis and investigation.

a) - Copular Be omitted:

- U.A.Q part of U.A.E

- Islam good for a person.

- When I ten years old.

- The tall buildings in Dubai beautiful and wonderful.

b) - Auxiliary Be omitted before [V-en]:

* I born in

* Our University College founded in 2014.

c) - Verb stem for [v-ed].

- I choose to specialize in English because

- I graduate from Al-Mua'lla Secondary School in2016.

- I come to study here.

d) - Verb stem for $[v+s]$.

- My father live in Ras Al-Khaimah.

- Our professor have good information.

- My mother work as a teacher.

e) - Is for are after there with plural nouns:

- There is 25 students in my class.

- There is two bedrooms in my house.

- There is not any hotels in my town.

f) - $[\mathbf{B e}+\mathbf{s t e m}]$ for $[$ stem $\underline{+\mathbf{s}] \text { : }}$ 
- I am work

- My professors are speak too fast for me to understand.

- My brother is live in-----------.

6) - The percentage of all types of errors for each group of subjects was calculated by dividing the number of all wrong verb forms by the number of all the obligatory context( i.e wrong forms + correct forms) in which a verb should have occurred correctly, then multiplying by one hundred.

7) - The percentage of all types of errors for each group of subjects was calculated by dividing the number of errors of this type by the number of the obligatory context in which this type of error should have occurred.

8) - Comparisons between each two groups ( as mentioned in the hypotheses) were made on the basis of the percentages calculated in the way mentioned in steps (6) and (7) above.

9) - A further investigation of these errors dealt with explanation of the learning strategies and reasons behind the occurrence of such errors.

\subsubsection{For Lexical Use}

1) - While reading the worksheets, the verbs that were lexically misused were indicated by writing the correct lexical item above the error.

2) - The number of each group's lexical verb errors was calculated.

3) - The number of the lexically correct verb uses was calculated.

4) - Percentages were computed by dividing the number of errors for each group by the number of both correct and incorrect lexical uses and then multiplying by one-hundred.

5) - Comparisons between each two groups (as mentioned in the hypotheses) were made on the basis of the percentages calculated in the way mentioned in step (4).

6) - In trying to categorize these lexical misuses, it was clear that they all were in the substitution category; a verb is substituted by another. The following are some examples from the data:

I make [for do] my homework.

Studying in a university have [for needs] a lot of money.

I teach [for learn or study] at Emirates Canadian University College.

7) - The next step dealt with explaining the causes behind the occurrence of such lexical errors. 


\section{Findings of the Study}

The four recorded groups produced different amounts of speech and, consequently, different numbers of verbs. The greatest number of verbs, being produced by the three second-year English- major students, was [353], which was not far greater than the [385]verbs produced by the three first-year-English- major students.

The other two groups of non-English-major students produced far smaller numbers of verbs, compared to those produced by the English - major students; thus, the three first- year non-English- major students produced a number of [130] verbs, and the three second-year-non-English major students produced a number of [109] verbs

It is worth mentioning that comparisons were made only between the two groups of English-major students on one hand, and between the two groups of non-English -major students on the other hand. No comparisons were made between the English-major students and the non- English - major students.

It is of interest, here, before proceeding to give the specific differences between each two groups on each of the specific error categories, to shed light on the differences in the overall competence between each two groups. Tables [1] and [2] below show the total percentages of all errors produced by the groups. Comparisons between each two groups on the basis of these total percentages may help in gaining a general estimate of the overall language competence of these four groups.

Table 1. Percent and number of errors of first and second- year English-major students

\begin{tabular}{|l|c|c|c|c|c|c|c|}
\hline Grade level & $\begin{array}{c}\text { Number of } \\
\text { grammatical } \\
\text { errors }\end{array}$ & $\begin{array}{c}\text { Number } \\
\text { of lexical } \\
\text { errors }\end{array}$ & $\begin{array}{c}\text { Total } \\
\text { number } \\
\text { of errors }\end{array}$ & $\begin{array}{c}\text { Total } \\
\text { number } \\
\text { of verbs }\end{array}$ & $\begin{array}{c}\text { Percent of } \\
\text { grammatical } \\
\text { errors }\end{array}$ & $\begin{array}{c}\text { Percent } \\
\text { of lexical } \\
\text { errors }\end{array}$ & $\begin{array}{c}\text { Total } \\
\text { percent }\end{array}$ \\
\hline $1^{\text {st }}$ year & 120 & 20 & 140 & 385 & $31.16 \%$ & $5.19 \%$ & $36.36 \%$ \\
\hline $2^{\text {nd }}$ year & 101 & 7 & 108 & 453 & $28.61 \%$ & $1.98 \%$ & $30.59 \%$ \\
\hline
\end{tabular}

Table 2. Percent and number of errors of first and second- year non-English-major students

\begin{tabular}{|l|c|c|c|c|c|c|c|}
\hline Grade level & $\begin{array}{c}\text { Number of } \\
\text { grammatical } \\
\text { errors }\end{array}$ & $\begin{array}{c}\text { Number } \\
\text { of lexical } \\
\text { errors }\end{array}$ & $\begin{array}{c}\text { Total } \\
\text { number } \\
\text { of errors }\end{array}$ & $\begin{array}{c}\text { Total } \\
\text { number } \\
\text { of verbs }\end{array}$ & $\begin{array}{c}\text { Percent of } \\
\text { grammatical } \\
\text { errors }\end{array}$ & $\begin{array}{c}\text { Percent } \\
\text { of lexical } \\
\text { errors }\end{array}$ & $\begin{array}{c}\text { Total } \\
\text { percent }\end{array}$ \\
\hline $1^{\text {st }}$ year & 55 & 7 & 62 & 130 & $42.30 \%$ & $5.38 \%$ & $47.68 \%$ \\
\hline $2^{\text {nd }}$ year & 45 & 3 & 48 & 109 & $41.28 \%$ & $2.75 \%$ & $44.03 \%$ \\
\hline
\end{tabular}




\section{Macrothink}

The results in tables [1] and [2] indicated that second -year English major students and non-English-major students have a higher degree of accuracy in the use of the English verb-forms than the first-year English - major and the non-English- major students.

When the percentages were calculated for the groups of errors under specific categories taking into consideration the number of obligatory context in which these types of errors should have occurred, it was clear that the degrees of accuracy varied among the four groups.

Table 3. Percent and number of errors of the first and second- year -English -major students on the separate error categories

\begin{tabular}{|l|c|c|c|c|c|c|}
\cline { 2 - 7 } \multicolumn{1}{l|}{} & \multicolumn{3}{c|}{ First-year } & \multicolumn{3}{c|}{ Second -year } \\
\hline Category & of errors & $\begin{array}{c}\text { Number } \\
\text { of } \\
\text { obligatory } \\
\text { contexts }\end{array}$ & percent & Number & $\begin{array}{c}\text { Number of } \\
\text { obligatory } \\
\text { contexts }\end{array}$ & percent \\
\hline Copula[Be] omitted & 13 & 87 & $14.94 \%$ & 4 & 50 & $8 \%$ \\
\hline $\begin{array}{l}\text { [Be] omitted before } \\
\text { [v-en] }\end{array}$ & 12 & 13 & $92.30 \%$ & 8 & 10 & $80 \%$ \\
\hline [Stem]_for [Stem +s] & 12 & 24 & $50 \%$ & 16 & 25 & $64 \%$ \\
\hline Stem for v-ed & 12 & 22 & $54.54 \%$ & 23 & 32 & $71.87 \%$ \\
\hline $\begin{array}{l}\text { [Is] for [are] after } \\
\text { [there] }\end{array}$ & 10 & 12 & $83.33 \%$ & 12 & 25 & $48 \%$ \\
\hline $\begin{array}{l}\text { [Be+ stem] for [stem } \\
\text { +s] }\end{array}$ & 10 & 72 & $13.88 \%$ & 9 & 113 & $7.96 \%$ \\
\hline
\end{tabular}

Table 3 revealed that second-year -English -major students show a more accurate use of the copular $[\mathrm{Be}]$ and the auxiliary [Be] than the first-year-English-major students. Although the differences between them are not significant, they may indicate some improvement. It is worth mentioning, here, that the high percentages of the two groups $(92.30 \% \& 80 \%)$ in the case of the auxiliary $[\mathrm{Be}]$ before the past participle is a problematic area facing both groups while using it.

Table 4. Percent and number of errors of first and second- year non-English-major students on the separate error categories

\begin{tabular}{|l|c|c|c|c|c|c|}
\cline { 2 - 6 } \multicolumn{1}{c|}{} & \multicolumn{3}{c|}{ First-year } & \multicolumn{3}{c|}{ Second -year } \\
\hline Category & Number & $\begin{array}{c}\text { Number } \\
\text { of } \\
\text { of errors } \\
\text { obligatory }\end{array}$ & percent & $\begin{array}{c}\text { Number } \\
\text { of errors }\end{array}$ & $\begin{array}{c}\text { Number of } \\
\text { obligatory } \\
\text { contexts }\end{array}$ & percent \\
\hline
\end{tabular}




\section{Macrothink}

\begin{tabular}{|l|c|c|c|c|c|c|}
\hline & & contexts & & & & \\
\hline Copula[Be] omitted & 7 & 21 & $33.33 \%$ & 16 & 32 & $50 \%$ \\
\hline $\begin{array}{l}\text { [Be] omitted before } \\
\text { [v-en] }\end{array}$ & 6 & 6 & $100 \%$ & 9 & 10 & $90 \%$ \\
\hline [Stem] for [Stem +s] & 18 & 22 & $82 \%$ & 4 & 7 & $57 \%$ \\
\hline$\underline{\text { Stem for v-ed }}$ & 9 & 13 & $69 \%$ & 10 & 17 & $59 \%$ \\
\hline $\begin{array}{l}\text { [Is] for [are] after } \\
\text { [there] }\end{array}$ & $\mathbf{5}$ & 5 & $100 \%$ & 3 & 3 & $100 \%$ \\
\hline $\begin{array}{l}\text { [Be+ stem] for [stem } \\
+\mathbf{s}]\end{array}$ & 5 & 30 & $17 \%$ & 2 & 33 & $6 \%$ \\
\hline
\end{tabular}

It is of great interest to see that first-year non-English-major students, as shown in table [4], showed a higher level of accuracy in using copular [be] than the second -year non-English-major students which proves that, regardless of the idiosyncratic factors, learners do not improve.

It is also revealed that the percentages of the two groups of non-English -major students errors while using the auxiliary [be] before past participle is one of the problematic areas in dealing with the English verb-forms.

As seen in table [4] the second-year non-English-major students showed a higher level of accuracy in the use of inflection of verbs for the past [-ed] and for the third person singular [-s] than did the first-year non-English-major students. But table [3] revealed that the first year English-major students showed a higher degree of accuracy in using [Stem for V-ed \& Stem for stem $+\mathrm{s}$ ] than the second -year English major students, which may be due to the nature of the courses given to the second-year English-major students during this semester, where the emphasis is on content rather form; on communication rather than grammatical rules.

Although the percentages computed in table [3] for the two groups of English-major students on [is for are after there] showed that this type of error is developmental, it proved to be one of the problematic areas in dealing with verb forms for the two groups of non-English-major students as shown in table [4] where we can see that they both got $100 \%$.

As shown in table [3] that the results related to [be + stem for stem $+\mathbf{s}$ ] showed that there were no significant differences between each two groups, this type of errors proved to be developmental in each of the two comparisons made. But, it is very important, here, to compare the English -majors with non-English -majors. The percentages of this type of errors produced by the non-English -major students were less than the percentages of errors produced by the two groups of English- major students. The may indicate that English -major students employ a wider range of overgeneralization strategies than do the non-English -major students. 


\section{$\triangle 1$ Macrothink}

Table 5. summary of the four groups' errors in the lexical use of verbs

\begin{tabular}{|l|c|c|c|c|c|c|}
\cline { 2 - 7 } \multicolumn{1}{c|}{} & \multicolumn{3}{c|}{ English-Major Students } & \multicolumn{3}{c|}{ Non-English-Major Students } \\
\cline { 2 - 7 } \multicolumn{1}{c|}{} & No. of errors & $\begin{array}{l}\text { No. of correct \& } \\
\text { incorrect uses }\end{array}$ & percent & No. of errors & $\begin{array}{l}\text { No. of correct \& } \\
\text { incorrect uses }\end{array}$ & percent \\
\hline First -Year & 10 & 245 & $4.08 \%$ & 7 & 102 & $6.86 \%$ \\
\hline Second-year & 8 & 295 & $2.71 \%$ & 3 & 68 & $4.41 \%$ \\
\hline
\end{tabular}

Table 5 above indicates a very small number of verbs were lexically misused by the four groups. What is remarkable, here, is that the comparisons made show that these errors are developmental in the sense that the more the learners are exposed to English; the more they increase their repertoire of lexical items.

\section{Discussion of the Results}

Error analysis could both provide teachers with information about second language learning processes and identify the needs of the individual learners. Its value is in showing what learners in fact do when they produce the second language and in revealing their developing strengths and weaknesses when struggling to obtain competence in the foreign language.

This study attempted to describe the errors in verb forms produced by Emirates Canadian University College students, to explain the reasons behind their occurrence, to identify the strategies employed by these students in learning and producing English as a second language and consequently suggest some pedagogical implications for teaching so that these weaknesses can be easily overcome.

The first and the second error categories can be explained with reference to the native language where the verb [be] does not exist. So, due to the incomplete acquisition of the English language rules, the student uses the native language rules in learning the English Language.

The other four categories can be explained with reference to some factors within the English Language itself.

The third and the fourth categories of errors show that the learners' great motivation to communicate in the second language, which makes them use the simplification strategy where the morphemes that do not carry the main meaning are dropped.

The learners in the fifth and the sixth categories of errors can be said to have employed the strategy of overgeneralization where the rules of the target language are used in inappropriate situations. Since [is] is more widely used after [there] than [are] [is] is used with countable singular nouns and uncountable nouns while [are] is used only with countable plural nouns], learners tend to overgeneralize the use of [is] everywhere. And this may also indicate that this type of error is an induced error due to the teaching learning variables. There might not have 
been enough emphasis and practice on the use of [are] after [there] with countable plural nouns.

The last category of grammatical errors is due to overgeneralization of present continuous [be] for simple present without [be]. And this may again due to the teaching learning factors especially that kind of exercises in which learners are required to transform the simple present structures into the present continuous ones.

\section{Lexical Errors}

According to Hernandez (2011)( as cited in Ewie, C and Miss Rebecca,2017), lexical errors are mistakes at the word level, which include, for example, choosing the wrong word for the meaning the writer wants to express. LLach (2015) said that "Lexical errors are very interesting, because they provide researchers with insightful information that help determine the evolution of the lexical profile of learners at these stages. Furthermore, lexical errors might also help in discriminating among proficiency levels (p.110). Carter (1998) said "When inappropriate lexical choices are made, they can lead directly to misunderstanding of the message, or at least to an increase in the burden of interpreting the text." (p.112)

In analyzing the lexical errors, only four out of the twenty lexical errors proved to be due to transfer from the first language. Examples from the data are as follows:

- My sister make [for works] at Umm Al-Quwain Bank.

- I live in a small village in Ras Al-Khaimah, but it is enjoy. [for funny].

Some of lexical errors were due to graphic similarity between the error and the correct form, which means that the learner knows the verb, but has not acquired it completely. The following are examples from the data collected:

- I wash [for wish] to visit you as soon as possible.

Some other lexical errors were explained to be induced errors, and these are due to methods of teaching and the existing curricula. The learners were taught some verbs, such as [ask and tell/ speak, tell say and talk/ learn, teach and study / been to and gone to/ let, make and be allowed to/ damage and ruin/ lend and borrow/ take and have ----etc.] but they may not have been taught the differences between each two verbs and they may also have not been given enough practice on using them. The following are chosen examples from the data:

- He does not want to tell [for talk] about it.

- I teach [for study] at English language and Translation Department at Emirates Canadian University Collge.

- My mother never make [ for let] me stay out till mid night.

Lastly, some of the errors were due to overextension strategy where the learners used the forms they knew for forms they might have not have known or might have forgotten at the moment. The following are some examples taken from the data: 
- Studying abroad have [for needs] too much money.

- I lived [for stayed] in a hotel for two weeks.

\section{Conclusions}

Based on this study, the following conclusions are highlighted:-

* Most of the errors made by the learners were inter-language errors.

* Overgeneralization and simplification strategies are the prime strategies employed by the learners.

* Motivation to communicate may surpass motivation to produce grammatical sentences correctly.

* Interference [language transfer] of the first language accounted for a high percentage of the most frequent errors.

* Simplification strategy is the most common strategy used by the learners.

* A very little and slow benefit from instructions is shown in the acquisition of English grammatical morphemes.

* English - major students should be exposed to special remedial courses in which they have adequate practice on the production of the basic structures of the English Language.

\section{Pedagogical Implications}

Error analysis plays a vital role in teaching-learning process. It identifies the students' strengths and weaknesses and, consequently, what they really need. So, error analysis should be frequently done by foreign language learners in trying to improve their competence in the foreign language. Upon the findings of this study some pedagogical implications were suggested for English teachers and instructors, policy makers and teaching process

$>$ In presenting a language material we should begin with those items that can be acquired easily so that they can become advanced organizers to the more difficult items.

$>$ A mere repetition does not help the learners much, they should be given the opportunity to produce situational English, both in speaking and writing, that will help them test their hypotheses.

$>$ At first, language production should be guided and then gradually becomes free. For instance, the teacher may give his/her students a passage to summarize or some questions to find answers for and then to say orally what they found.

$>$ A distinction should be drawn between the language items that are graphically similar i.e homophones, for instance, [rain-reign- rein/ sail-sale/ lie-lay/ wood-would/ way-weigh/to-too-two/ son-sun/ one-won/which-witch/ quite-quiet---etc.], and encourage the learners to practice each. 
$>$ A distinction should also be drawn between verbs that may cause confusion, such as [ask and tell/ speak- tell -say and talk/ learn- teach and study / been to- gone to/ let- make - be allowed to/ damage - ruin/ lend - borrow/ take -have/ make-do/ ], and the learners should be given an opportunity to practice them.

$>$ Learners' errors should not be looked upon as signs of failure but as indicators to the learners' "built-in-syllabus." Corder, 1974, upon which our foreign-language curriculum should be based.

$>$ Sometimes, a contrast should be made between the English and the Arabic languages while presenting the second language material. For example, a teacher should draw his/her students' attention to the non-existence of the verb [be] in the Arabic Language and its existence in the English Language, and then draw a comparison between structures from both languages.

$>$ While teaching a grammatical feature, it should be associated with meaningful situations and learners should have appropriate practice on the production of such structure.

Finally, this study recommends that in-service- English Language teachers and instructors should be given special courses in which they learn how to deal with their learners' developmental errors, explain them and try to find remedial methods for correcting and overcoming such errors.

$>$ Teachers and university professors must encourage learners to practice speaking English inside and outside classrooms through playing games, singing, reading aloud, meeting English speakers, acting drama and role play and practicing free online learning activities.

$>$ Schools, colleges and universities must have English clubs where students can practice oral production.

\section{References}

Abd-Karim, N. and Mohamed, I.A.S. (2014). An Analysis of Speech Errors of English for Occupational Purposes ( EOP) Learners at the International Islamic University Malaysia (IIUM). Middle- East Journal of Scientific Research, 20, 58-66.

Abu shihab. I.(2014). An Analysis of Grammatical Errors in Writing Made by Turkish Learners of English as a Foreign Language. International Journal of Linguistics, 6(4), 213-223.

Al-Ahmadi, N.S. (2014). Error Analysis: A Case Study of Saudi Learner's Grammatical Speaking Errors. Arab World English Journal. International Peer-Reviewed Journal. ISSN: 2229-9327, 5, 4, 84-98.

Bootchuy, T. (2008). An Analysis of Errors in Academic English Writing by a Group of First - Year Thai Graduates Majoring in English. Master's Thesis. Kasetsart University. Retrieved December 7, 2011 from http://research.rdi.ku.ac.th/world/cache/57/TiptidaBOOAll.pdf

Carter, R. (1998). Vocabulary: Applied linguistics perspectives (2nd ed.). London: Routledge. 


\section{Macrothink}

Journal for the Study of English Linguistics

ISSN 2329-7034 2019, Vol. 7, No. 1

Chamot, A.U. (1978). "Strategies in Acquisition of English by a Child Bilingual in Spanish and French," Paper Presented at the Colloquium on the Acquisition and Use of Spanish and English as First and Second Languages. TESOL, April, 4- 9.

Corder, S.P. (1974). "The Significance of the Learner's Errors," in J.H. Schumann and N. Stenson (eds.). New Frontiers in Second Language Learning. Rowley. Massachusetts: Newbury House, 90-99.

Dulay, H. et al. (1982). Language Two. New York: Oxford University Press.

Enquist, M.I. (1980). “The Morpheme Acquisition of an Adult Spanish Speaker Learning English as a Second Language," Dissertation Abstracts International A, 40, 4.

Ervin- Tripp, S.M.(1978). “Second Language Learning Like the First?” in E.M. Hatch (ed.). Second Language Acquisition: a book of Readings. Rowley. Massachusetts: Newbury House, 190-206.

Farhat, S. H. (1994). Error analysis: A study of the written performance of University of Khartum freshmen. (Master's thesis). Khartum University, Sudan.

Hernandez, M.S. (2011). Raising Students Awareness about Grammatical and Lexical Errors via Email. Revista de Lenguas Modernas, 4, 263-281.

James, C. (1998). Errors in language learning and use. London: Longman.

Kovac, M, M. (2011). Speech Errors in English as Foreign Language: A Case Study of Engineering Students in Croatia. English Language and Literature Studies, 1(1), 20-39.

LLach, P.A.(2015). Lexical Errors in Writing at the End of Primary and Secondary Education: Description and Pedagogic Implications. Porta Linguarum, 23, 109-124.

Madden, B.N.C. and S.D. Krashen (1978). Is there a "Natural Sequence" in Adult Second Language Learning? In Second Language Acquisition. In E.M. Hatch (ed.) Rowley. Massachusetts: Newbury House, 262-370.

Mariko, A. (2007). Grammatical Errors Across Proficiency Levels in L2 Spoken and Written English. The e-Economic Journal of Takasaki City University of Economics, 49(3), 117-129.

Mohaghegh, H., et.al. (2011). Grammatical errors produced by English majors: The translation task. Educational Research and Reviews, 6(16), 87-88.

Mushin, M.A. (2016). Analyzing the Students Errors in Using Simple Present (A case Study at Junior High School in Makassar. Pacific Science Review B: Humanities and Social Sciences, 2, 81-87.

Nassaji H. (2011). Correcting students' written grammatical errors: The effects of negotiated versus non-negotiated feedback. Studies in Second Language Learning and Teaching, 3(1), 315-334. 
Owu-Ewie C, Lomotey CF. L1 (Akan)(2016). Interference errors in L2 (English) writing: The case of three junior high school students in Ghana. American Journal of Language and Literacy, 1, A1-A18.

Phettongkam. H. (2013). Error Analysis and its Implications in Communicative English Language Teaching. Thammasat Review, Special issue.

Ravem, R. (1974). “Two Norwegian Children's Acquisition of English Syntax,” in E.M. Hatch (ed.). Second Language Acquisition: a book of Readings. Rowley. Massachusetts: Newbury House, 148-154.

Rezai,M. J.\& Masood Heshmatian.( 2013). Spoken morphological errors made by Iranian EFL learners. TELL, 7, 1, 121-149.

Richards J.C. (1971). A non-contrastive approach to error analysis. English Language Teaching, 253.

Richards, J. C. (1990). Error analysis: Perspectives on second language acquisition. Routledge.

Richards, J.C. (1974). "Error Analysis and Second Language Strategies," in J.H.Schumann and N. Stenson (eds.). New Frontiers in Second Language Learning. Rowley. Massachusetts: Newbury House, 32-53.

Ruiminar, H. (2018). Grammatical Errors in ESP Students' Presentation Across Proficiency Levels. En Jour Me (English Journal of Merdeka): Culture, Language, and Teaching of English, 3, 1, 15-22.

Saad, M.A and Murad ,H.M.S. (2014). Error Analysis in Role-Play Presentations among Less Proficient L2 Malaysian Learners. International Journal of English and Education, 3, 3, 346-355.

Şena, Y and Mesut ,K. (2017). Use of plural in spoken English in an EFL context. Eurasian Journal of Applied Linguistics, 3, 2,139-153.

Steinberg, D.D. (1999). Psycholinguistics: Language, mind and world. London: Longman.

Sudhakaran, B. (2008). The use of Prepositions among Malay Adult ESL Learners. Unpublished doctoral thesis, University Putra Malaysia.

Sukasame, N. \& et.al. ( 2014). A Study of Errors in Learning English Grammatical Structures on Tenses of Matthayomsuksa 4 Students of the Demonstration School, Khonkaen University. Procedia-Social and Behavioral Sciences. 116, 1934-1939.

Tahrinian, M.H. (1979). "A Study of the Acquisition Problems of Different Aspects of English by Learners Who Acquire the Language in a Non-English Speaking Environment," Dissertation Abstracts International A, 39, 9. 


\section{Macrothink}

Journal for the Study of English Linguistics

ISSN 2329-7034 2019, Vol. 7, No. 1

Tarawneh, R. T. and Islam, M.A.(2013). The Spoken Errors and Mistakes Committed by Senior English Students at Princess Alia University College. Theory and Practice in Language Studies, 3,3 ,497-502.

Ting, S. H. and et.al (2010). Grammatical Errors in spoken English of University students in oral communication course. GEMA Journal of language Studies, 10.10, 53-70.

Willcott, P.J. (1972). An analysis of the written English of native speakers of Arabic as found in American History final examination given at the University of Texas at Austin. Unpublished Ph.D. Dissertation, The University of Texas at Austin, U.S.A.

Yoon, H.K (2012). Grammar Errors in Korean EFL Learners' TOEIC Speaking Test. English Teaching, 67, 4, 287-309.

\section{Copyright Disclaimer}

Copyright for this article is retained by the author(s), with first publication rights granted to the journal.

This is an open-access article distributed under the terms and conditions of the Creative Commons Attribution license (http://creativecommons.org/licenses/by/3.0/). 